\title{
Pengembangan Perangkat Pembelajaran Matematika melalui Pendekatan Scaffolding Berbasis Karakter
}

\author{
Hendri Handoko ${ }^{1^{*}}$ dan Winarno ${ }^{2}$ \\ Pendidikan Matematika, IAIN Syekh Nurjati Cirebon \\ Jalan Perjuangan by Pass Sunyaragi, Cirebon, Jawa Barat, Indonesia \\ 1*hendrihandoko.iain.crb@gmail.com \\ Pendidikan Matematika, SMA Negeri 1 Tanjung \\ Jalan Cemara No. 01 Tanjung, Brebes, Jawa Tengah, Indonesia \\ 2winarno32@gmail.com
}

Artikel diterima: 09-08-2019, direvisi: 25-09-2019, diterbitkan: 30-09-2019

\begin{abstract}
Abstrak
Persoalan di lapangan menunjukkan banyak guru yang belum mampu mengembangkan perangkat pembelajaran sesuai dengan kemampuan siswa. Hal tersebut menyebabkan fungsi guru yang seharusnya inovatif, kreatif, mengarahkan, membimbing dan memberikan solusi terhadap permasalahan yang dihadapi siswa tidak berjalan dengan maksimal. Penelitian pengembangan ini bertujuan menghasilkan perangkat pembelajaran yang valid, praktis dan efektif melalui pendekatan scaffolding berbasis karakter mengacu model Thiagarajan. Instrumen yang digunakan yaitu lembar pengamatan karakter kemandirian, keterampilan berpikir kreatif, kemampuan guru mengelola kelas, angket respon siswa, validasi perangkat pembelajaran, dan instrumen TKBK. Subjek penelitian adalah siswa SMAN 1 Tanjung kelas X.MIPA 2 berjumlah 33 orang. Hasil penelitian menunjukkan bahwa perangkat pembelajaran yang dikembangkan valid, pembelajaran matematika dinyatakan efektif dengan ketuntasan rata-rata kelas 76,70 dan ketuntasan klasikal $85 \%$, adanya pengaruh positif karakter kemandirian dan keterampilan terhadap kemampuan berpikir kreatif sebesar 0,782, serta adanya perbedaan signifikan kemampuan berpikir kreatif kelas eksperimen dengan rata-rata 76,70 lebih baik dari kelas kontrol sebesar 70,24.

kata kunci: pendekatan scaffolding, karakter, berpikir kreatif
\end{abstract}

\section{Development of Mathematics Learning through Character-Based Scaffolding Approach}

\begin{abstract}
The problem in the field shows that many teachers have not been able to develop learning tools that are adapted to students' abilities. so the teacher's function that should be innovative, creative, directing, guiding and providing solutions to problems faced by students cannot run optimally. This development study aims to produce valid, practical and effective learning tools through characterbased scaffolding approaches referring to the Thiagarajan model. The instruments used were independent character observation sheets, creative thinking skills, teacher's ability to manage classrooms, student response questionnaires, validation of learning devices, and TKBK instruments. The research subjects were 33 students of SMAN 1 Tanjung class X.MIPA 2. The results showed that the learning tools developed were valid, positive response of students $87 \%$, Mathematics learning is declared effective by (1) completeness of class average 76.70 and achieving classical completeness $85 \%$, the positive influence of the character of independence and skills on the ability to think creatively by 0.782 , and there is a significant difference in the creative thinking ability of the experimental class with an average of 76.70 better than the control class of 70.24

Keyword: scaffolding approach, character, creative thinking.
\end{abstract}




\section{Pendahuluan}

Kehidupan manusia hampir tidak pernah terlepas dari kegiatan belajar, baik ketika beraktivitas sendiri maupun berkelompok. Aktivitas belajar merupakan tindakan yang disengaja atau dirancang oleh siswa itu sendiri sebagai output suatu aktivitas khusus yang ada di kehidupan (Hamdu, 2011). Abidin (2013:6) mengemukakan bahwa pembelajaran adalah gabungan aktivitas dimana siswa sebagai pemeran utama guna memperoleh tujuan hasil belajar atas bimbingan, motivasi dan saran guru. Pada hakikatnya belajar merupakan suatu kegitan yang dilakukan baik sadar maupun tidak sadar oleh setiap individu. Seperti yang dikemukakan oleh Cleopatra (2015) bahwa belajar adalah proses yang sangat kompleks yang dialami semua orang secara terus menerus hingga adanya perubahan tingkah laku.

Guru dapat menyelenggarakan pembelajaran yang baik apabila tujuan awal dan khusus tercapai (Anggraini, 2016). Kegiatan pembelajaran melatih kemampuan siswa agar mampu mengkonstruksi pengetahuannya sendiri. Oleh karena itu, fungsi mental dan psikis harus dikembangkan melalui keterampilan yang ada di diri siswa. Dalam proses konstruksi itu, menurut Glasersfeld (Aunurrahman, 2009) diperlukan beberapa kemampuan dasar, yaitu: (1) dapat secara lancar mengungkapkan yang pernah diingat dan berdasarkan pengalaman, (2) dapat menentukan keputusan dari hasil membandingkan, terkait perbedaan dan kesamaan, serta (3) rasa lebih menyukai suatu pengalaman daripada yang lain.

Penerapan berpikir kreatif yang dilakukan oleh siswa yaitu menyelesaikan masalah matematika yang diawali dengan perencanaan untuk membuat langkahlangkah hingga sampai jawaban akhir (Fitriani dan Yarmayani, 2018). Belajar matematika merupakan aktivitas berpikir kreatif dengan memberi jawaban yang lengkap dan sistematis. Siswa mengalami kesulitan menjawab soal matematika diawali dengan kurang memahami soal matematika yang menyebabkan susah merencanakan penyelesaian (Riyanto, Mariani 2020). Belajar matematika yang optimal terjadi ketika siswa mengembangkan cara-cara yang efektif untuk menyelesaikan permasalahan. Berpikir kreatif dalam matematika dapat ditunjukkan oleh siswa melalui fleksibilitas memecahkan berbagai masalah matematika (Mahmudi dan Saputro, 2016). Kegiatan mental belajar ini sangat sulit dilihat atau diobservasi kecuali bila kegiatan belajar tersebut diikuti dengan kegiatan fisik.

Masalah yang muncul pada pembelajaran matematika khususnya pada materi Dimensi Tiga telah diteliti sebelumnya oleh Handoko (2017) diantaranya, (1) Dalam dimensi dua siswa masih kesulitan memahami gambar dan dimensi tiga karena belum terbiasa berpikir abstraksi lebih tinggi; (2) kemampuan pemahaman terkait materi prasyarat sebelumnya seperti segitiga dan trigonometri sangat dibutuhkan, saat ini 
siswa mengalami kesulitan untuk menemukan hubungan matematika yang dipelajari; (3) Metode ceramah masih digemari oleh guru dalam menggunakan metode pembelajaran; (4) Adanya keterbatasan pemakaian media dan beberapa sumber belajar lainnya, baik dari sisi kuantitas maupun kualitas. Oleh karena itu, siswa kesulitan untuk mencapai pemahaman belajar matematika yang berdampak kepada pencapaian tujuan hasil belajar. Upaya yang dapat dilakukan oleh guru adalah mengembangan perangkat dan proses pembelajaran dengan pendekatan scaffolding berbasis pendidikan karakter kemandirian siswa

Pengembangan perangkat pembelajaran dengan pendekatan scaffolding berbasis pendidikan karakter mandiri berarti mengembangkan perangkat yang pembelajarannya dirancang dengan pendekatan scaffolding berbasis pendidikan karakter mandiri dan substansi perangkat pembelajarannya memenuhi indikator-indikator pendekatan scaffolding. Perangkat pembelajaran yang dimaksud meliputi (1) Silabus, (2) Rencana Pelaksanaan Pembelajaran (RPP), (3) Lembar Kerja Siswa (LKS), (4) Buku Ajar Siswa (BAS), dan (5) Tes Kemampuan Berpikir Kreatif (TKBK)

Pembelajaran dengan pendekatan scaffolding diartikan pendekatan yang berpedoman kepada pemberian bantuan dari guru agar siswa belajar dan mampu memecahkan satu masalah (Puspita dan Sapir, 2012). Sedang karakter kemandirian menurut Elfindri (2012) merupakan perilaku dan sikap yang enggan mudah untuk meminta pertolongan orang lain agar menemukan solusi atas tugas atau masalah yang dialami. Pendekatan scaffolding dapat diartikan sebagai pemberian khusus dukungan untuk belajar yang umumnya diberikan saat awal pembelajaran agar mewujudkan belajar mandiri (Nurhayati, 2017).

Alur pembelajaran dengan pendekatan scaffolding berbasis karakter kemandirian diawali dengan penyelarasan ruang kelas, pembagian tugas terstruktur, masingmasing siswa bekerja secara individu, siswa menyelesaikan tugas dengan berkelompok, merefleksikan pembelajaran secara individu atau kelompok, menyampaikan gagasan individu, dan simpulan atau penutup. Alur kegiatan tersebut memungkinkan siswa menemukan cara alternatif untuk penyelesaian sebagai aplikasi keterampilan berpikir kreatif.

Menurut Wallas (Pangestu dan Yunianta, 2019) keterampilan siswa yang dibangun saat pembelajaran berpikir kreatif di antaranya (1) siswa terbiasa melakukan persiapan belajar; (2) inkubasi; (3) iluminasi; (4) dan verifikasi. Indikator Kemandirian belajar siswa selama proses pembelajaran menurut Babys (2017) yaitu: (1) Initiative (prakarsa); (2) Improvisation (pengembangan/ penyempurnaan) (3); Pro-active (aktif); (4) Creativity (daya cipta); dan (5) Innovation (pembaharuan/ penemuan baru).

Rumusan masalah dalam penelitian adalah mendeskripsikan bagaimana

\section{Mosharafa: Jumal Pendidikan Matematika}


pengembangan dan hasil pengembangan perangkat pembelajaran matematika yang valid, praktis dan efektif dengan pendekatan scaffolding berbasis karakter pada materi Dimensi Tiga kelas X MIPA SMA.

Sedangkan penelitian ini bertujuan untuk mengembangan perangkat pembelajaran matematika yang valid, praktis dan serta menguji keefektifan pembelajaran matematika dengan pendekatan scaffolding berbasis karakter pada materi Dimensi Tiga kelas X.MIPA SMA yang efektif.

\section{Metode}

Penelitian ini merupakan penelitian pengembangan yaitu mengembangkan suatu perangkat pembelajaran untuk pelajaran matematika dengan pendekatan scaffolding untuk meningkatkan kemampuan berpikir kreatif siswa pada materi dimensi tiga mengacu pada model pengembangan Thiagarajan, Semmel dan semmel (1974) yang dimodifikasi. Model pengembangan Thiagarajan yang dimodifikasi terdiri dari tiga tahap yaitu: (1) tahap pendefinisian, (2) tahap perancangan, (3) tahap pengembangan.

Subjek penelitian adalah siswa SMAN 1 Tanjung kelas X.MIPA 2 berjumlah 33 orang. Instrumen penelitian yang digunakan untuk mengumpulkan data terdiri atas lembar pengamatan karakter kemandirian, keterampilan berpikir kreatif, kemampuan guru mengelola kelas, angket respon siswa, validasi perangkat pembelajaran, dan instrumen TKBK. 414
Metode pengumpulan data yang diterapkan untuk penelitian ini di antaranya metode tes, pengamatan, wawancara, dan angket.

Analisis data validitas perangkat yaitu data hasil penilaian para ahli untuk setiap aspek dari setiap perangkat yang dikembangkan dianalisis disesuaikan dengan skor rata-rata. Perangkat pembelajaran dikatakan valid jika mendapat kategori penilaian baik dan sangat baik.

Analisis data kepraktisan yang ditetapkan menggunakan analisis data pengamatan kemampuan guru mengelola pembelajaran yaitu dengan cara menghitung jumlah skor tiap indikator dari pengamatan dibagi banyaknya item pernyataan dengan rating scale skor teringgi 4 dan analisis angket respon siswa terhadap pembelajaran dihitung dengan membagi jumlah skor pernyataan yang diperoleh siswa dibagi dengan banyaknya siswa.

Analisis uji keefektifan memerlukan uji prasyarat yang harus dilakukan, yaitu uji normalitas dan homogenitas. Analisis data akhir dalam penelitian ini berupa nilai tes kemampuan berpikir kreatif sebagai hasil belajar yaitu uji ketuntasan rata-rata kelas dan klasikal dalam mencapai KKM.

Uji ketuntasan rata-rata kelas menggunakan uji proporsi satu pihak. Sedangkan uji ketuntasan klasikal dengan menggunakan uji rata-rata satu pihak. Rumus yang digunakan dalam menganalisis uji ketuntasan klasikal yaitu dengan uji t dengan membandingkan $t_{\text {tabel }}$ 
dengan $d k=n-1$ dengan kriteria pengujian $5 \%$. $H_{0}$ ditolak jika $t_{\text {hitung }}>t_{(1-\alpha)}$ (Sudjana, 2005).

Analisis uji regresi ganda dalam penelitian ini menggunakan program SPSS 16. $H_{0}$ ditolak jika nilai sig lebih kecil dari 5\%. Selanjutnya untuk mengetahui besarnya pengaruh kontribusi variabel $X_{1}$ dan $X_{2}$ terhadap $\hat{Y}$ dapat dilihat dari nilai $R$ square (Sukestiyarno, 2012). Uji beda digunakan uji proporsi satu pihak, rumus yang digunakan uji z. Selanjutnya hasil tersebut dibandingkan dengan nilai $Z_{\text {tabel }}$ dengan kriteria pengujian $5 \%$. $H_{0}$ diterima jika $\left.z_{\text {hitung }}>z_{(0,5-} \alpha\right)$. Untuk mengetahui peningkatan kemandirian belajar dan keterampilan berpikir kreatif siswa pada kelas uji coba perangkat berdasarkan pengamatan dapat dilihat berdasarkan grafik peningkatan selama kegiatan uji coba

\section{HASIL DAN PEMBAHASAN}

Kegiatan pertama dalam penelitian ini yaitu melakukan validasi. Validasi dilakukan dengan tujuan untuk mendapatkan saran perbaikan sekaligus merupakan penilaian para ahli terhadap rancangan pengembangan perangkat. Saran dari para ahli tersebut digunakan sebagai landasan penyempurnaan pengembangan perangkat yang telah disusun. Validasi desain perangkat pembelajaran merupakan suatu proses kegiatan untuk menilai apakah rancangan produk akan lebih baik dari yang lama atau tidak (Sugiyono, 2011)

Validator dalam penelitian terdiri dari 5 orang, yaitu 3 orang dosen dan 2 orang guru mata pelajaran matematika. Pengembangan perangkat hasil revisi berdasarkan masukan dari validator selanjutnya diujicobakan pada siswa kelas X.MIPA SMAN 1 Tanjung tahun pelajaran 2017/2018. Hasil validasi dapat ditunjukkan pada tabel 1.

Ahmadi dkk (2011) mengemukakan perangkat dikatakan praktis jika menunjukkan apa yang dikembangkan dapat diterapkan dan kenyataan menunjukkan bahwa apa yang mereka

Tabel 1.

Hasil Validasi Perangkat Pembelajaran

\begin{tabular}{|c|c|c|c|c|c|c|}
\hline \multirow[t]{2}{*}{ No } & \multirow[t]{2}{*}{ Validator } & \multicolumn{5}{|c|}{ Rata-rata Hasil Validasi } \\
\hline & & Silabus & RPP & BAS & LKS & TKBK \\
\hline 1 & $\mathrm{~V}-1$ & 4,20 & 3,88 & 4,00 & 4,00 & 4,00 \\
\hline 2 & $\mathrm{~V}-2$ & 3,44 & 3,84 & 3,80 & 3,80 & 4,00 \\
\hline 3 & V-3 & 3,36 & 3,28 & 3,20 & 3,27 & 3,50 \\
\hline 4 & V-4 & 3,84 & 3,96 & 4,00 & 3,80 & 3,80 \\
\hline 5 & V-5 & 3,24 & 3,32 & 3,33 & 3,33 & 3,20 \\
\hline \multicolumn{2}{|r|}{ Jumlah } & 18,08 & 18,28 & 18,33 & 18,20 & 18,50 \\
\hline \multicolumn{2}{|c|}{ Rata-rata } & 3,62 & 3,66 & 3,67 & 3,64 & 3,70 \\
\hline \multicolumn{2}{|c|}{ Klasifikasi } & Baik & Baik & Baik & Baik & Baik \\
\hline \multicolumn{2}{|c|}{ Keterangan } & $\mathrm{V} / \mathrm{RK}$ & V/RK & $\mathrm{V} / \mathrm{RK}$ & V/RK & $\mathrm{V} / \mathrm{RK}$ \\
\hline
\end{tabular}


kembangkan betul-betul dapat diterapkan. Penggunaan perangkat pembelajaran dikatakan praktis dalam penelitian ini yaitu dengan melihat kemampuan guru mengelola kelas dan respon siswa terhadap perangkat pembelajaran. Hasil pengamatan kemampuan guru mengelola kelas dapat ditunjukkan pada tabel 2 .

Hasil angket siswa diambil secara purposive sampling dari subjek penelitian dengan mengambil 6 siswa yang terdiri dari siswa berkemampuan tinggi, sedang dan rendah yang masing-masing 2 orang. Hasil dapat ditunjukkan pada tabel 3.

Hasil pada tabel 3 menunjukkan bahwa

Tabel 2.

Rekapitulasi Nilai Kemampuan Guru (KG)

\begin{tabular}{|c|c|c|c|c|c|c|}
\hline \multirow{2}{*}{$\begin{array}{l}\mathrm{N} \\
\mathrm{O} .\end{array}$} & \multirow{2}{*}{$\begin{array}{c}\text { Kode } \\
\text { Observer }\end{array}$} & \multicolumn{5}{|c|}{ Jumlah Skor Pertemuan Ke- } \\
\hline & & 1 & 2 & 3 & 4 & 5 \\
\hline 1. & OB-1 & 88 & 91 & 94 & 95 & 97 \\
\hline 2. & OB-2 & 89 & 91 & 93 & 95 & 96 \\
\hline \multirow{2}{*}{\multicolumn{2}{|c|}{$\begin{array}{l}\text { Rata-rata } \\
\text { Skor Tiap } \\
\text { Pertemuan }\end{array}$}} & 3,5 & 3,6 & 3,7 & 3,8 & 3,8 \\
\hline & & 4 & 4 & 4 & 0 & 6 \\
\hline \multicolumn{2}{|c|}{$\begin{array}{l}\text { Rata-rata Skor } \\
\text { KG }\end{array}$} & \multicolumn{5}{|c|}{3,72} \\
\hline
\end{tabular}

Tabel 3.

Rekapitulasi Hasil Angket Siswa

\begin{tabular}{|ccccccc|}
\hline \multirow{1}{*}{ N } & Siswa & \multicolumn{5}{c}{ Jumlah Skor Pertemuan Ke- } \\
\cline { 2 - 7 } o. & & 1 & 2 & 3 & 4 & 5 \\
\hline 1 & S-1 & 88 & 88 & 90 & 90 & 92 \\
\hline 2 & S-2 & 90 & 88 & 90 & 88 & 92 \\
\hline 3 & S-3 & 86 & 88 & 90 & 90 & 88 \\
\hline 4 & S-4 & 87 & 88 & 88 & 88 & 90 \\
\hline 5 & S-5 & 82 & 82 & 83 & 84 & 85 \\
\hline 6 & S-6 & 82 & 83 & 82 & 84 & 84 \\
\hline $\begin{array}{c}\text { Rata-rata } \\
\text { Skor Tiap }\end{array}$ & 85. & 86. & 87. & 87.33 & 88. \\
Pertemuan & & 17 & 17 & & 50 \\
\hline $\begin{array}{c}\text { Rata-rata } \\
\text { Skor }\end{array}$ & & & & \\
\hline
\end{tabular}

kemampuan guru mengelola kelas dengan nilai rata-rata sebesar 3,72 dari skor tertinggi 4,00 atau termasuk dalam kategori sangat baik. Hasil tabel 3 menunjukkan respon siswa diperoleh skor $87 \%$, dengan ketentuan bahwa respon siswa dikatakan positif jika diperoleh skor lebih dari 80\%. Dengan demikian dapat disimpulkan bahwa pembelajaran dengan pendekatan scaffolding berbasis karakter materi Dimensi Tiga kelas X.MIPA praktis.

Pembelajaran matematika dikatakan efektif dalam penelitian ini jika, (1) pembelajaran dengan menggunakan pendekatan scaffolding mencapai tuntas KKM; (2) adanya pengaruh positif karakter mandiri dan keterampilan berpikir kreatif terhadap kemampuan berpikir kreatif; (3) adanya perbedaan signifikan kemampuan berpikir kreatif siswa pada pembelajaran dengan pendekatan scaffolding (kelas eksperimen) lebih baik dibandingkan dengan pembelajaran konvensional (kelas kontrol). Berdasarkan data yang diperoleh kemudian dinalisis untuk menguji keefektifan pembelajaran di atas.

Analisis uji pencapaian ketuntasan ratarata kelas digunakan uji proporsi satu pihak, hal ini dilakukan untuk mengetahui apakah banyaknya siswa yang mencapai ketuntasan telah mencapai sekurangkurangnya 85\%. Dengan menggunakan uji $z$, hasil perhitungannya adalah tolak $\mathrm{Ho}$ jika Znitung $>Z_{\text {tabel }}$. Pada kelas eksperimen didapatkan $Z_{\text {hitung }}=2,619$ dan $Z_{\text {tabel }}=1,64$ dengan taraf signifikansi 5\% maka $\mathrm{Ho}$ ditolak, sehingga dapat disimpulkan proporsi siswa kelas yang diberi perlakuan 
pembelajaran scaffolding dengan KKM 70 telah mencapai 85\%.

Adapun uji ketuntasan klasikal pencapaian KKM terhadap data nilai kemampuan berpikir kreatif kelas uji coba perangkat dengan menggunakan uji ratarata satu pihak. Hasil dapat ditunjukkan pada tabel 4.

Dari hasil analisis pada table 4 data yang diperoleh adalah nilai rata-rata kelas $(\bar{x})=76,70$; nilai rata-rata yang dihipotesiskanKKM $\left(\mu_{o}\right)=70$; simpangan baku sampel $(s)=8,32$; banyak sampel ( $n$ ) = 33 dengan menggunakan taraf signifikan $5 \%$ dan $d k=(33-1)=32$ diperoleh nilai $t_{\text {tabel }}=1,64$. Dengan demikian diperoleh $t_{\text {hitung }}>t_{\text {tabel }}$ dengan $t_{\text {hitung }}=8,32>1,64$, sehingga $\mathrm{Ho}$ ditolak yang berarti rata-rata kemampuan berpikir kreatif kelas uji coba perangkat lebih besar dari 70. Jadi Kemampuan berpikir kreatif siswa mencapai tuntas KKM. Hasil ketuntasan tes kemampuan berpikir kreatif ditunjukkan pada tabel 5.

Berdasarkan dari out put One Sample Test pada Tabel 5 diketahui nilai $t=4,624$, dengan sig $=0,000$. Karena nilai $\operatorname{sig}=0,000<0,05$, maka $H_{0}$ ditolak. Artinya rata-rata ketuntasan belajar kelas yang diberi perlakuan pembelajaran scaffolding (kelas eksperimen) $>70$, dengan rata-rata hasil $T K B K=76,70$. Hal ini membuktikan bahwa hipotesis "ratarata hasil tes kemampuan berpikir kreatif siswa pada kelas yang diberi perlakuan pembelajaran dengan pendekatan
Scaffolding berbasis karakter mencapai kriteria ketuntasan belajar minimal".

Data karakter kemandirian siswa dan keterampilan berpikir kreatif diambil dari hasil pengamatan yang dilakukan oleh observer dan data kemampuan berpikir kreatif diambil melalui tes kemampuan berpikir kreatif (TKBK). Hasil ditunjukkan pada tabel 6 dan tabel 7.

Berdasarkan hasil yang diperoleh nilai $R$ Square $=0,782$ atau $78,20 \%$. Hal ini berarti 78,20\% kemampuan berpikir kreatif siswa dipengaruhi oleh karakter kemandirian dan keterampilan berpikir kreatif siswa dalam menyelesaikan soal dan terdapat $21,80 \%$ dipengaruhi oleh faktor lain.

Tabel 4.

Rataan Hasil Tes Kemampuan Berpikir Kreatif (KBK)

\begin{tabular}{ccccc}
\hline & $N$ & Mean & $\begin{array}{c}\text { Std. } \\
\text { Deviation }\end{array}$ & $\begin{array}{c}\text { Std. } \\
\text { Error } \\
\text { Mean }\end{array}$ \\
\hline TKBK & 33 & 76.70 & 8.320 & 1.448
\end{tabular}

Tabel 5.

Ketuntasan Hasil Tes Kemampuan Berpikir Kreatif Test Value $=70$

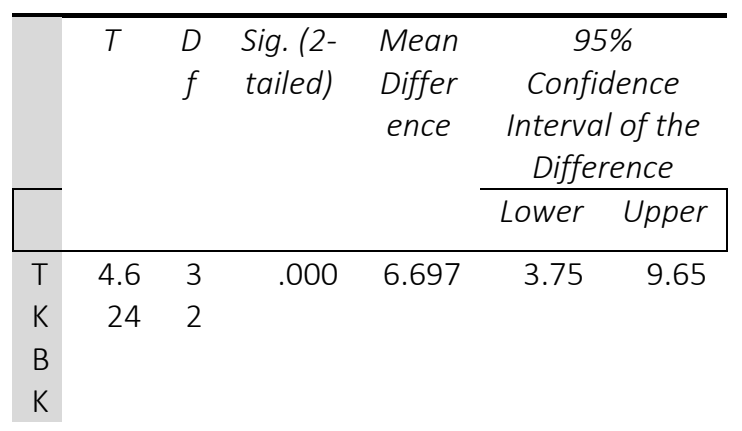

Tabel 6

Output Model Summary

\begin{tabular}{llcrr}
\hline Model & $R$ & $\begin{array}{c}R \\
\text { Squar } \\
e\end{array}$ & $\begin{array}{c}\text { Adjuste } \\
d R \\
\text { Square }\end{array}$ & $\begin{array}{c}\text { Std. Error } \\
\text { of the } \\
\text { Estimate }\end{array}$ \\
\hline 1 & $.884^{\mathrm{a}}$ & .782 & .767 & 4.014 \\
\hline & & & & \\
\hline
\end{tabular}


Sedangkan persamaan regresinya adalah $\hat{Y}=-21,088+0,719 X_{1}+0,617 X_{2}$, artinya setiap penambahan variabel karakter mandiri siswa $\left(X_{1}\right)$ sebesar satu satuan maka akan menambah nilai tes kemampuan berpikir kreatif $(Y)$ sebesar 0,719 dan setiap penambahan variabel keterampilan berpikir kreatif $\left(X_{2}\right)$ sebesar satu satuan maka akan terjadi penambahan nilai tes kemampuan berpikir kreatif $(Y)$ sebesar 0,617.

Analisis uji keefektifan selanjutnya yaitu uji banding dengan membandingkan hasil kelas eksperimen dengan kelas kontrol. Hasil dapat ditunjukkan pada tabel 8.

Berdasarkan data hasil tes kemampuan berpikir kreatif yang diperoleh kelas eksperimen dengan perlakuan pembelajaran pendekatan scaffolding dan kelas kontrol dengan pembelajaran konvensional diperoleh rata-rata kelas eksperimen $(\bar{x})=76,70$ dan kelas kontrol ( $\bar{x})=70,24$. Hasil ini dapat disimpulkan bahwa kelas eksperimen lebih baik dari kelas kontrol. Data juga dianalisis dengan uji proporsi yaitu uji $z$ diperoleh hasil perhitungannya yaitu tolak $H_{0}$ jika Znitung $>Z_{\text {tabel. }}$ Pada kelas eksperimen didapatkan $z_{\text {hitung }}=8,673$ dan $z_{\text {tabel }}=1,64$ dengan taraf signifikansi 5\% maka $H_{0}$ ditolak, sehingga dapat disimpulkan bahwa proporsi siswa yang telah menc apai tuntas KKM pada kelas eksperimen lebih besar dari kelas control.

Dari hasil validasi ke lima validator diperoleh rata-rata nilai perangkat silabus $=3,62 ; \mathrm{RPP}=3,66 ; \mathrm{BAS}=3,67$; LKS = 3,64; dan $\operatorname{TKBK}=3,70$. Nilai ini menunjukkan pada kriteria baik. Untuk pengembangan perangkat soal TKBK bertujuan untuk menghasilkan instrumen soal yang memenuhi kriteria valid, reliable, mempunyai tingkat kesukaran seimbang, dan daya pembeda yang baik/signifikan.

Butir soal sebagai produk akhir dari soal TKBK harus memenuhi empat kriteria tersebut di atas. Berdasarkan hasil perhitungan validasi butir soal, maka soal

Tabel 7.

Output Coefficients Persamaan Regresi Ganda

\begin{tabular}{|c|c|c|c|c|c|}
\hline \multicolumn{2}{|c|}{ Model } & \multicolumn{2}{|c|}{ Unstandardized Coefficients } & \multirow{2}{*}{$\begin{array}{c}\text { Standardized Coefficients } \\
\text { Beta }\end{array}$} & \multirow[t]{2}{*}{$T$} \\
\hline & & $B$ & Std. Error & & \\
\hline \multirow[t]{3}{*}{1} & (Constant) & -21.088 & 9.480 & & -2.224 \\
\hline & Karakter_Mandiri & .719 & .239 & .503 & 3.002 \\
\hline & Keterampilan_BK & .617 & .250 & .413 & 2.463 \\
\hline
\end{tabular}

Tabel 8.

\begin{tabular}{llcccc}
\hline & \multicolumn{7}{c}{ Output Group Statistics } & & \\
\hline & Kelas & $N$ & Mean & Std. Deviation & $\begin{array}{c}\text { Std. Error } \\
\text { Mean }\end{array}$ \\
\hline TKBK & kelas eksperimen & 33 & 76.70 & 8.320 & 1.448 \\
\cline { 2 - 6 } & kelas kontrol & 34 & 70.24 & 9.471 & 1.624 \\
\hline
\end{tabular}


TKBK yang digunakan adalah yang respon siswa terhadap proses memenuhi kriteria, (1) valid atau pembelajaran dengan pendekatan mempunyai nilai Korelasi Product Moment $\left(r_{x y}\right)$ dengan minimal kriteria sedang; (2) mempunyai derajat realibilitas tinggi dan berdasarkan hasil perhitungan diperoleh nilai 0,8061 menunjukkan derajat realibilitasnya tinggi, (3) butir soal yang mempunyai indeks kesukaran seimbang; dan (4) butir soal mempunyai daya pembeda yang baik.

Hasil dari validasi dan revisi sesuai masukan dari validator ini disebut sebagai draf final yang selanjutnya digunakan sebagai bahan uji coba pada kelas uji coba perangkat, yakni kelas yang diberi perlakuan dengan pembelajaran pendekatan scaffolding berbasis karakter (kelas eksperimen).

Hasil perhitungan dari lembar pengamatan kemampuan guru dalam mengelola kelas pada pembelajaran dengan pendekatan scaffolding berbasis karakter mandiri mempunyai rata-rata sebesar 3,72, yang berarti berdasarkan kriteria yang telah ditetapkan maka kemampuan guru dalam mengelola kelas termasuk dalam kategori sangat baik.

Hasil perhitungan angket respon siswa terhadap kegiatan pembelajaran matematika dengan scaffolding berbasis karakter kemandirian mempunyai persentase respon positif sebesar $87 \%$ sedang persentase respon negatif $13 \%$. Berdasarkan kriteria yang telah ditetapkan bahwa respon siswa dikatakan positif jika rata-rata persentase jawaban respon siswa $\geq 80 \%$, maka hal ini menunjukkan bahwa scaffolding berbasis karakter kemandirian mempunyai respon yang positif.

Efektifitas pembelajaran diantaranya, uji ketuntasan yang meliputi ketuntasan rata-rata kelas dan ketuntasan klasikal. Dari uji ketuntasan sesuai dengan KKM = 70 , hasilnya menunjukkan nilai rata-rata ketuntasan TKBK pada kelas eksperimen adalah 76,70, dan berdasarkan hasil uji proporsi data TKBK siswa yang memperoleh nilai $>70$ telah mencapai $85 \%$. Dengan demikian dapat disimpulkan bahwa TKBK siswa yang mengikuti pembelajaran dengan pendekatan scaffolding berbasis karakter materi Dimensi Tiga kelas $X$ telah mencapai kriteria ketuntasan minimal sebesar $85 \%$, sehingga perangkat pembelajaran efektif mengantarkan siswa untuk mencapai tuntas KKM, baik ketuntasan rata-rata kelas maupun ketuntasan klasikal. Hal ini dapat dikatakan bahwa pendekatan scaffolding berbasis karakter kemandirian berhasil meningkatkan kemandirian dan keterampilan berpikir kreatif siswa kearah positif terutama dalam kerja sama saling membimbing sesama teman dan saling membantu dalam menyelesaikan permasalahan.

Berdasarkan hasil uji regresi ganda dengan perhitungan SPSS 16 diperoleh nilai $R$ Square $=0,782$, yang berarti $78,20 \%$ besarnya pengaruh karakter kemandirian dan keterampilan berpikir kreatif terhadap kemampuan berpikir kreatif siswa. 
Hasil uji banding terhadap nilai TKBK menunjukan rata-rata tes kelas eksperimen yang menggunakan pengembangan perangkat pembelajaran dengan pendekatan scaffolding berbasis karakter sebesar 76,70 lebih baik dibandingkan dengan kelas kontrol yang pembelajarannya menggunakan metode konvensional sebesar 70,24. Hasil juga dapat dilihat dari peningkatan pada kelas eksperimen, yakni dari nilai rata-rata sebesar 44,88 menjadi 76,70. Berdasarkan analisis SPSS 16 pada Output Independent Samples T-Test kolom t-test for Equality of Means diperoleh nilai sig 0,004<0,05 yang berarti rata-rata TKBK kelas eksperimen yang pembelajarannya diberi perlakuan dengan pengembangan perangkat menggunakan pendekatan scaffolding berbasis karakter lebih baik dibandingkan dengan kelas kontrol yang pembelajarannya menggunakan metode konvensional.

Hasil ini didukung oleh penelitian yang dilakukan Kusworo dan Hardianto (2009) bahwa pembelajaran dengan Penerapan pendekatan pembelajaran scaffolding dapat meningkatkan hasil belajar IPS (ekonomi) dalam nilai afektif, psikomotorik, dan kognitif pada siswa kelas VIII - I SMP Negeri 8 Malang. Penelitian yang dilakukan oleh Puspita dan Sapir (2012) juga menyimpulkan bahwa, penerapan pembelajaran teknik scaffolding dapat meningkatkan hasil belajar siswa dan nilai rata-rata kelas. Dari 30 siswa yang belum diberikan pembelajaran tekhnik scaffolding terdapat 16 siswa yang belum tuntas belajar, dengan nilai rata-rata kelas hanya 70 dan belum mencapai ketuntasan klasikal. Setelah diberikan penerapan pembelajaran teknik scaffolding jumlah siswa yang tuntas menjadi 28 atau ketuntasan klasikal mencapai 93\% dengan rata-rata nilai kelas sebesar 90 .

\section{Penutup}

Pengembangan perangkat pembelajaran matematika dengan pendekatan scaffolding berbasis karakter materi Dimensi Tiga menggunakan model Thiagarajan dimodifikasi dinyatakan valid dan mendapatkan validasi dari tim ahli dan rekan sejawat. Hasil validasi meliputi silabus 3,62 (valid), RPP 3,66 (valid), BAS 3,67 (valid), LKS 3,64 (valid), dan TKBK 3,70 (valid). Perangkat praktis dimana kemampuan guru mengelola pembelajaran sangat baik dengan skor rata-rata 3,72 dan respon siswa positif sebesar $87 \%$. Pembelajaran efektif, yaitu (1) kemampuan berpikir kreatif siswa pada kelas eksperimen mencapai ketuntasan dengan melampaui $\mathrm{KKM}=70$ dan proporsi lebih dari 85\%; (2) terdapat pengaruh positif karakter kemandirian dan keterampilan berpikir kreatif terhadap kemampuan berpikir kreatif siswa sebesar 78,20\%; (3) adanya perbedaan signifikan kemampuan berpikir kreatif kelas eksperimen dengan nilai rata-rata 76,70 dan kelas kontrol 70,24. 
Penelitian pengembangan perangkat dengan pendekatan scaffolding berbasis karakter seyogyanya dapat dijadikan sebagai media atau sarana bagi siswa maupun guru untuk berlatih dalam mengembangkan kemampuan, keterampilan, serta untuk mengasah pembiasaan berpikir kreatif dan kritis dalam pembelajaran matematika dengan tetap memperhatikan penyusunan perangkat pembelajaran yang sesuai dengan materi dan diberikan dengan menggunakan model atau strategi yang menarik sehingga siswa tidak mengalami kejenuhan dalam belajar.

\section{Daftar PUStaka}

Abidin, Y. (2013). Desain Sistem Pembelajaran dalam Konteks Kurikulum 2013. Bandung: PT. Refika Aditama.

Ahmadi, I.K., Setyono, H.A., dan Amri, S. (2011). Pembelajaran Akselerasi (Analisis Teori dan Praktik serta Pengaruhnya terhadap Mekanisme Pembelajaran dalam Kelas Akselerasi. Jakarta: Prestasi Pustaka Publisher.

Anggraini, I. S. (2016). Motivasi Belajar dan Faktor-Faktor yang Berpengaruh: Sebuah Kajian Pada Interaksi Pembelajaran Mahasiswa. Premiere Educandum: Jurnal Pendidikan Dasar dan Pembelajaran, 1(02).

Babys, U. (2017). Kemampuan Literasi Matematis Space and Shape Dan Kemandirian Siswa SMA Pada Discovery Learning Berpendekatan
RME-PISA. JPMI (Jurnal Pendidikan Matematika Indonesia), 1(2), 43-49.

Cleopatra, M. (2015). Pengaruh gaya hidup dan motivasi belajar terhadap prestasi belajar matematika. Formatif: Jurnal IImiah Pendidikan MIPA, 5(2).

Elfindri. (2012). Pendidikan Karakter Kerangka, Metode dan Aplikasi untuk Pendidikan dan Profesional. Jakarta: Baduose Media Jakarta.

Fitriani, S., \& Yarmayani, A. (2018). Pengembangan Rubrik Berpikir Kreatif Siswa Menengah Atas dalam Menyelesaikan Masalah Matematika. Mosharafa: Jurnal Pendidikan Matematika, 7(1). 33-38. DOI: https://doi.org/10.31980/moshar afa.v7i1.339

Hamdu, G., \& Agustina, L. (2011). Pengaruh motivasi belajar siswa terhadap prestasi belajar IPA di sekolah dasar. Jurnal penelitian pendidikan, 12(1), 90-96.

Handoko, H. (2017). Pembentukan Keterampilan Berpikir Kreatif Pada Pembelajaran Matematika Model Savi Berbasis Discovery Strategy Materi Dimensi Tiga Kelas X. Eduma: Mathematics Education Learning and Teaching, 6(1).

Kusworo, P., \& Hardinto, P. (2009). Efektivitas Penerapan Pendekatan Pembelajaran Scaffolding dalam Ketuntasan Belajar Ekonomi Siswa Kelas X SMA Labortorium Universitas Negeri Malang. Jurnal Pendidikan Ekonomi, 2(1). 
Mahmudi, A., \& Saputro, B. A. (2016). Analisis Pengaruh Disposisi Matematis, Kemampuan Berpikir Kreatif, dan Persepsi pada Kreativitas terhadap Kemampuan Pemecahan Masalah Matematis. Mosharafa: Jurnal Pendidikan Matematika, 5(3), 205-212.

DOI: https://doi.org/10.31980/moshar afa.v5i3.276

Nurhayati, E. (2017). Penerapan scaffolding untuk pencapaian kemandirian belajar siswa. JP3M (Jurnal Penelitian Pendidikan dan Pengajaran Matematika), 3(1).

Pangestu, N. S., \& Yunianta, T. N. H. (2019). Proses Berpikir Kreatif Matematis Siswa Extrovert dan Introvert SMP Kelas VIII Berdasarkan Tahapan Wallas. Mosharafa: Jurnal Pendidikan Matematika, 8(2). 215226.

DOI: https://doi.org/10.31980/moshar afa.v8i2.472

Puspita, M. L. (2012). Penerapan pembelajaran konstruktivistik teknik scaffolding pada mata pelajaran IPS (ekonomi) untuk meningkatkan hasil belajar ekonomi siswa kelas VIII-I SMPN 8 Malang.

Riyanto, O. R., \& Mariani, S. (2020).

Mathematics Critical Thinking

Reviewed from Self-efficacy and

Motivation of Learning in Arias

Learning. Journal of Primary

Education, 243-250.

Sudjana. (2005). Metode Statistika.

Bandung: Tarsito.
Sugiyono. (2011). Metode Penelitian Pendidikan Pendeketan Kuantitatif, Kualitatif, dan R\&D. Bandung: Alfabeta.

Sukestiyarno. (2012). Olah Data Penelitian Berbantuan SPSS 16. Semarang: Universitas Negeri Semarang

Thiagarajan, S., Semmel, D.S. \& Semmel, M.I. (1974). Instructional Development for Training Teachers of Exceptional Children. Indiana: Indiana University Bloomington

\section{Riwayat Hidup Penulis}

Hendri Handoko, M. Pd.

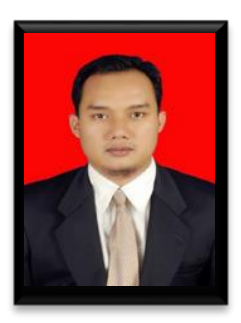

Lahir di Brebes, 2 Agustus 1981. Staf pengajar di Institut Agama Islam Negeri (IAIN) Syekh Nurjati Cirebon. Studi S1 Pendidikan Matematika di Universitas Muhammadiyah Surakarta (UMS), lulus tahun 2006; S2 Pendidikan Matematika di Universitas Negeri Semarang (UNNES), lulus tahun 2013.

\section{Winarno, M.Pd.}

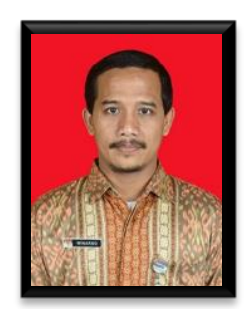

Lahir di Brebes, 25 Agustus 1979. Guru matematika di SMA Negeri Tanjung. Studi S1 Pendidikan Matematika di IKIP PGRI Semarang, lulus tahun 2003; S2 Pendidikan Matematika di Universitas Negeri Semarang (UNNES), lulus tahun 2013. 